\title{
Does bleeding affect fetal Doppler parameters during genetic amniocentesis?
}

\author{
Cantekin İskender ${ }^{1}$, Ebru Tanım², Tayfun Çok ${ }^{2}$, Hakan Kalaycr' ${ }^{2}$ Ayşe Parlakgümüş², Cem Yalçınkaya² \\ 'Department of Perinatology, Dr Zekai Tahir Burak Research and Training Hospital, Ankara, Turkey \\ ${ }^{2}$ Department of Obstetrics and Gynecology, Basskent University Faculty of Medicine, Adana, Turkey
}

\section{Abstract}

Objective: The aim of this study was to investigate the relationship between fetal Doppler parameters and bleeding at insertion points during amniocentesis.

Material and Methods: This prospective study was conducted between July 2010 and February 2011. A total of 215 amniocentesis procedures were performed during this period. Five patients with Down syndrome were excluded from the study. The remaining 210 patients were divided into Group 1 (bleeding at insertion site) and Group 2 as a control group. One needle type was used for all patients. Umbilical artery resistance index (UARI), umbilical artery pulsatility index (UAPI), middle cerebral artery resistance index (MCARI), middle cerebral artery pulsatility index (MCA PI), and middle cerebral artery peak systolic velocity (MCAPSV) were measured immediately and before and after amniocentesis.

Results: Bleeding at the insertion point during amniocentesis did not significantly change the UARI (34\% increase for Group 1 and $46.5 \%$ increase for Group 2, $\mathrm{p}=0.238$ ), the MCARI ( $52 \%$ increase for Group 1 and $45 \%$ increase for Group 2, $\mathrm{p}=0.622$ ), or the MCAPSV (37\% increase for Group 1 and 49\% increase for Group 2, $\mathrm{p}=0.199$ ). UARI, MCARI, MCA PI, and MCAPSV were not significantly altered following amniocentesis in Groups 1 and 2. There was a significant increase in UAPI following amniocentesis only in Group 2.

Conclusion: Bleeding during genetic amniocentesis did not change umbilical artery and middle cerebral artery Doppler parameters.

(J Turk Ger Gynecol Assoc 2014; 15: 100-3)

Key words: Amniocentesis, bleeding, fetal Doppler

Received: 06 March, 2014

Accepted: 18 April, 2014

\section{Introduction}

Amniocentesis is the most commonly performed invasive prenatal diagnostic procedure. Although technically simple, it may result with in pregnancy loss. The total pregnancy loss rate due to amniocentesis is the sum of the procedural and the background loss rates (1). Procedure-related fetal losses have been found to be associated with a procedure at 18 weeks or beyond, a procedure performed for abnormal second-trimester biochemical screening test, a bloody tap, and a female fetus but not to the number of punctures or transplacental amniocentesis (2-4). Although considered a complicating factor, transplacental needle passage during amniocentesis has not been shown to induce changes in fetal Doppler parameters when compared to a group with nontransplacental amniocentesis $(5,6)$.

In the present study, we aimed to investigate the relationship between fetal umbilical artery (UA) middle cerebral artery (MCA) Doppler parameters and bleeding at the insertion point during transplacental amniocentesis.

\section{Material and Methods}

This prospective study was conducted between July 2010 and February 2011. A total of 215 amniocentesis procedures were performed during this period. Five patients with Down syndrome were excluded from the study. The remaining 210 patients were divided into Group 1 (bleeding at the insertion site). Group 2 was the control group. One needle type was used for all patients. Bleeding from the insertion site was noted when jet flow from the placenta into the amniotic cavity was detected by ultrasonography. Umbilical artery resistance index (UARI), UA pulsatility index (UAPI), MCA resistance index (MCARI), MCA pulsatility index (MCA PI), and MCA peak systolic velocity (MCAPSV) were measured immediately and before and after amniocentesis. The study was conducted using a color Doppler instrument (ProSound $\alpha 10$, Aloka, Tokyo, Japan) with a $5 \mathrm{MHz}$ convex probe. For an accurate measurement, the fetal head was in the transverse plan. MCA vessels were detected with color Doppler ultrasound overlying the anterior wing of the sphenoid bone. An angle of insonation of $<15^{\circ}$ was used (near $0^{\circ}$ ). For fetal MCA 
peak systolic velocity, the highest velocity was used. All of the invasive procedures and Doppler evaluation were performed by a single operator. The study was approved by the ethics and educational issues coordinating committee of the institution where the study was conducted. All of the patients signed written consent that their data could be used with appropriate ethical committee approval prior to genetic amniocentesis.

\section{Statistical Analysis}

Statistical analysis was performed using SPSS (R) version 17 (SPSS; Chicago, IL, USA). An independent samples t-test was performed for parametric variables between groups. A paired samples t-test was performed for parametric variables within groups. A chi-square test was performed for non-parametric variables between groups. A P value less than 0.05 was considered significant.

\section{Results}

Characteristics of the study population are shown in Table 1. Maternal age and gestational age at amniocentesis were similar among groups. The distribution of nulliparity and indications for amniocentesis were also not significantly different between groups. Patients in Group 1 had significantly more frequent anterior placentation. UA and MCA Doppler characteristics are shown in Table 2. UARI and UAPI before and after amniocentesis were not different between patients in Groups 1 and 2 . Among patients in Group 1, 34\% had an increase in UARI and $43.5 \%$ had an increase in UAPI. Increased UARI and UAPI were observed in $46.5 \%$ and $57.5 \%$ of patients in Group 2, respectively. The ratio of patients with increased UARI and UAPI did not differ significantly between groups.

Middle cerebral artery pulsatility index was similar in both groups before and after amniocentesis. MCAPSV was similar between groups before and after amniocentesis. The number of fetuses with increased MCAPSV was also similar in Groups 1 and 2.

Changes in UA and MCA Doppler parameters within each group after amniocentesis are shown in Table 3. UARI, MCARI, MCA PI, and MCAPSV were not significantly altered following amniocentesis in Groups 1 and 2. There was a significant increase in UAPI following amniocentesis only in Group 2.

\section{Discussion}

The findings of the present study indicate that ultrasonographic evidence of bleeding as a result of transplacental needle passage during mid-trimester genetic amniocentesis does not influence Doppler parameters in the present study cohort.

It is debated whether transplacental needle passage significantly increases the rate of complications. Although some earlier reports did find an increase in fetal loss rates $(7,8)$, many other studies have not found such an association (9-11). Although convincing evidence is not present in terms of fetal loss, it has been shown that transplacental needle passage may lead to certain procedural complications, such as aspiration of hemorrhagic amniotic fluid or fetomaternal hemorrhage (FMH) (10).
Table 1. Clinical data of the study population

\begin{tabular}{|c|c|c|c|}
\hline & $\begin{array}{l}\text { Group } 1 \\
(n: 62)\end{array}$ & $\begin{array}{l}\text { Group } 2 \\
(\mathrm{n}: 153)\end{array}$ & $\mathbf{p}$ \\
\hline Maternal age [mean $(y) \pm S D]$ & $33.1 \pm 6.0$ & $33.7 \pm 6.7$ & 0.52 \\
\hline $\begin{array}{l}\text { Gestational age [mean } \\
\text { (weeks) } \pm \mathrm{SD}]\end{array}$ & $18.1 \pm 1.5$ & $17.8 \pm 1.8$ & 0.24 \\
\hline Nulliparity [n (\%)] & $25(40.3)$ & $45(29.4)$ & 0.11 \\
\hline $\begin{array}{l}\text { Indication of amniocentesis } \\
\text { [n (\%)] }\end{array}$ & & & 0.59 \\
\hline Advanced maternal age & $15(24.2)$ & $44(28.8)$ & \\
\hline Sonographic markers & $6(9.7)$ & $10(6.5)$ & \\
\hline Positive maternal screening & $38(61.3)$ & $91(59.5)$ & \\
\hline $\begin{array}{l}\text { Previous pregnancy with } \\
\text { aneuploidy }\end{array}$ & $3(4.8)$ & $8(5.2)$ & \\
\hline Placental location [n (\%)] & & & $0.001 *$ \\
\hline Anterior & 59 (95.2) & $50(32.7)$ & \\
\hline Posterior & 0 & $89(58.2)$ & \\
\hline Fundal & $1(1.6)$ & $10(6.5)$ & \\
\hline Lateral & $2(3.2)$ & $4(2.6)$ & \\
\hline \multicolumn{4}{|l|}{$\begin{array}{l}\text { Y: years; SD: standard deviation } \\
\text { *p<0.05 }\end{array}$} \\
\hline
\end{tabular}

Table 2. Comparison of umbilical artery and middle cerebral artery Doppler parameters before and after amniocentesis between two groups

\begin{tabular}{|l|c|c|c|}
\hline & $\begin{array}{c}\text { Group 1 } \\
\text { (n:62) }\end{array}$ & $\begin{array}{c}\text { Group 2 } \\
\text { (n:153) }\end{array}$ & p \\
\hline $\begin{array}{l}\text { Umbilical artery RI before } \\
\text { amniocentesis }\end{array}$ & $0.77 \pm 0.08$ & $0.78 \pm 0.07$ & 0.57 \\
\hline $\begin{array}{l}\text { Umbilical artery RI after } \\
\text { amniocentesis }\end{array}$ & $0.76 \pm 0.09$ & $0.79 \pm 0.08$ & 0.46 \\
\hline $\begin{array}{l}\text { Umbilical artery PI before } \\
\text { amniocentesis }\end{array}$ & $1.43 \pm 0.29$ & $1.45 \pm 0.27$ & 0.81 \\
\hline $\begin{array}{l}\text { Umbilical artery PI after } \\
\text { amniocentesis }\end{array}$ & $1.39 \pm 0.29$ & $1.51 \pm 0.36$ & 0.43 \\
\hline $\begin{array}{l}\text { No. of fetuses with an increase } \\
\text { in umbilical artery RI [n(\%)] }\end{array}$ & 21 (34) & $71(46.5)$ & 0.24 \\
\hline $\begin{array}{l}\text { No. of fetuses with an increase } \\
\text { in umbilical artery PI [n(\%)] }\end{array}$ & $27(43.5)$ & $88(57.5)$ & 0.07 \\
\hline MCA PI before amniocentesis & $1.61 \pm 0.36$ & $1.71 \pm 0.39$ & 0.21 \\
\hline MCA PI after amniocentesis & $1.62 \pm 0.4$ & $1.70 \pm 0.43$ & 0.63 \\
\hline MCA PSV before amniocentesis & $25.6 \pm 5.3$ & $24.5 \pm 4.4$ & 0.26 \\
\hline MCA PSV after amniocentesis & $24.2 \pm 5.3$ & $24.3 \pm 4.2$ & 0.58 \\
\hline $\begin{array}{l}\text { No. of fetuses with an increase } \\
\text { in MCA PSV [n(\%)] }\end{array}$ & $23(37)$ & $75(49)$ & 0.19 \\
\hline $\begin{array}{l}\text { RI: resistance index; PI: pulsatility index; MCA: middle cerebral artery; } \\
\text { PSV: peak systolic velocity }\end{array}$ & & \\
\hline
\end{tabular}

It has been previously hypothesized that hemorrhage into the amniotic cavity occurs in most cases when transplacental amniocentesis is performed (12). Visualization of blood jet from the placenta into the amniotic cavity provides ultrasono- 
Table 3. Changes in umbilical artery and middle cerebral artery Doppler parameters before and after amniocentesis within groups

\begin{tabular}{|l|c|c|}
\hline & Group 1 (n:62) & Group 2 (n:153) \\
\hline UARI change & $-0.01 \pm 0.08$ & $0.07 \pm 0.07$ \\
\hline UAPI change & $-0.04 \pm 0.31$ & $0.05 \pm 0.31 *$ \\
\hline MCARI change & $-0.02 \pm 0.12$ & $0.01 \pm 0.1$ \\
\hline MCA PI change & $0.01 \pm 0.48$ & $-0.01 \pm 0.42$ \\
\hline MCAPSV change & $-0.7 \pm 4.3$ & $-0.2 \pm 4.8$ \\
\hline $\begin{array}{l}\text { UA: umbilical artery; PI: pulsatility index; MCA: middle cerebral } \\
\text { artery; PSV: peak systolic velocity *p<0.05 }\end{array}$
\end{tabular}

graphic evidence of transplacental hemorrhage (13). Accurate estimation of the level of transplacental bleeding into the amniotic cavity may not be possible through ultrasonography alone. Testing for fetal erythrocytes in maternal circulation may be useful to detect the presence of FMH in this case. However, this may still be of limited value to evaluate the impact of bleeding on the fetus. In the present study, most of the cases of transplacental bleeding occurred in anteriorly located placentas. However, ultrasonographically detected bleeding did not occur in all cases of anteriorly located placentas.

Middle cerebral artery peak systolic velocity is used to evaluate fetuses with anemia due to various etiologies (14). While it is primarily used to detect severity of fetal anemia in red cell alloimmunization, it can be used to diagnose fetal anemia due to different causes. Several authors have demonstrated the validity of MCAPSV in detecting fetal anemia from other causes, such as congenital parvovirus infection and non-immune hydrops fetalis $(15,16)$. Most authors report a sensitivity of nearly $100 \%$ in experienced centers, although this may vary depending on the experience of the operator or the severity of the fetal anemia $(17,18)$. While the increase of MCAPSV is well established in chronic situations leading to fetal anemia, the role of Doppler studies in acute fetal blood loss is less clear. Results of two previous studies indicate that acute FMH also leads to an increase in MCAPSV. Baschat and associates have detected increased MCAPSV in a case of severe acute FMH, confirmed by the Kleihauer-Betke test (19). In a later study, Yamaguchi and associates demonstrated increased PSV of MCA in an actively bleeding fetus due to spontaneous rupture of a sacrococcygeal teratoma (20). To the best of our knowledge, no study has previously investigated the effect of transplacental bleeding on MCAPSV. Our results indicate that bleeding at amniocentesis did not significantly affect MCAPSV in our study population.

Most previous reports have stated that amniocentesis has no significant effect on umbilical artery Doppler parameters (5, $6,21)$, while others have found transient changes or changes attributable to maternal anxiety $(22,23)$. Two main conclusions can be inferred based on the results of these studies. The amount of fetomaternal bleeding is significantly below the limit that triggers fetal hemodynamic responses. In addition, the physiological reaction to placental puncture in the fetoplacental unit is sufficient to contain the acute insult. Our results are mostly consistent with previously published data, as we were unable to detect any significant changes, except for increased in UAPI in Group 2. As no bleeding or transplacental passage occurred in this group, we speculate that factors other than placental perforation and bleeding (such as transient uterine activity) might cause increased UAPI.

In conclusion, ultrasonographic evidence of bleeding is commonly encountered during transplacental mid-trimester amniocentesis. This complication is almost always self-limited and has no significant short-term consequences in terms of middle cerebral and umbilical artery Doppler parameters.

Ethics Committee Approval: Ethics committee approval was received for this study from the ethics committee of Başkent University.

Informed Consent: Written informed consent was obtained from patients who participated in this study.

Peer-review: Externally peer-reviewed.

Author contributions: Concept - C.I., E.T.; Design - C.I., E.T.; Supervision - E.T.; Materials - E. T., A.P., H.K., T.C..; Data Collection\&/or Processing - C.I., E.T., H.K., C.Y.; Analysis\&/or Interpretation - C.I., T.Ç., A.P., C.Y.; Literature Search - C.I.., E.T., H.K., C.Y.; Writing - C.I., E.T., H.K., Cem Yalçınkaya.; Critical Reviews - E.T.

Conflict of Interest: No conflict of interest was declared by the authors.

Financial Disclosure: The authors declared that this study has received no financial support.

\section{References}

1. Tabor A, Alfirevic Z. Update on procedure-related risks for prenatal diagnosis techniques. Fetal Diagn Ther 2010; 27: 1-7. [CrossRef]

2. Kong CW, Leung TN, Leung TY, Chan LW, Sahota DS, Fung TY, Lau TK. Risk factors for procedure-related fetal losses after midtrimester genetic amniocentesis. Prenat Diagn 2006; 26: 925-30. [CrossRef]

3. Dacus JV, Wilroy RS, Summitt R, Garbaciak JA, Abdella TN, Spinnato JA. Genetic amniocentesis: a twelve years' experience. Am J Med Genet 1985; 20: 443-52. [CrossRef]

4. Antsaklis A, Papantoniou N, Xygakis A, Mesogitis S, Tzortzis E, Michalas S. Genetic amniocentesis in women 20-34 years old: associated risks. Prenat Diagn 2000; 20: 247-50. [CrossRef]

5. Haugen G, Helbig A, Husby H. Umbilical artery Doppler flow velocity waveforms after transplacental amniocentesis. Obstet Gynecol 2003; 101: 697-703. [CrossRef]

6. Martinez JP, Comas C, Ojuel J, Puerto B, Borrell A, Fortuny A. Doppler assessment of umbilical flow after genetic amniocentesis. Early Hum Dev 1996; 44: 105-11. [CrossRef]

7. Tabor A, Philip J, Madsen M, Bang J, Obel EB, Nørgaard-Pedersen B. Randomised controlled trial of genetic amniocentesis in 4606 low-risk women. Lancet 1986; 1: 1287-93. [CrossRef]

8. Andreasen E, Kristoffersen K. Incidence of spontaneous abortion after amniocentesis: influence of placental localization and past obstetric and gynecologic history. Am J Perinatol 1989; 6: 268-73. [CrossRef]

9. Marthin T, Liedgren S, Hammar M. Transplacental needle passage and other risk-factors associated with second trimester amniocentesis. Acta Obstet Gynecol Scand 1997; 76: 728-32. [CrossRef] 
10. Kalogiannidis I, Prapa S, Dagklis T, Karkanaki A, Petousis S, Prapas Y, Prapas N. Amniocentesis-related adverse outcomes according to placental location and risk factors for fetal loss after midtrimester amniocentesis. Clin Exp Obstet Gynecol 2011; 38: 239-42.

11. Giorlandino C1, Mobili L, Bilancioni E, D’Alessio P, Carcioppolo O, Gentili P, Vizzone A. Transplacental amniocentesis: Is it really a higher-risk procedure? Prenat Diagn 1994; 14: 803-6. [CrossRef]

12. Athanasiadis AP, Pantazis K, Goulis DG, Chatzigeorgiou K, Vaitsi V, Assimakopoulos E, et al. Comparison between 20G and 22G needle for second trimester amniocentesis in terms of technical aspects and short-term complications. Prenat Diagn 2009; 29: 761-5. [CrossRef]

13. Subira' D, Uriel M, Serrano C, Castan ón S, Gonzalo R, Illa n J, et al. Significance of the volume of fetomaternal hemorrhage after performing prenatal invasive tests. Cytometry B Clin Cytom 2011; 80: 38-42. [CrossRef]

14. Mari G, Deter RL, Carpenter RL, Rahman F, Zimmerman R, Moise KJ Jr, et al. Noninvasive diagnosis by Doppler ultrasonography of fetal anemia due to maternal red-cell alloimmunization. Collaborative Group for Doppler Assessment of the Blood Velocity in Anemic Fetuses. N Engl J Med 2000; 342: 9-14. [CrossRef]

15. Cosmi E, Mari G, Delle CL, Detti L, Akiyama M, Murphy J, et al. Noninvasive diagnosis by Doppler ultrasonography of fetal anemia resulting from parvovirus infection. Am J Obstet Gynecol 2002; 187: 1290-3. [CrossRef]

16. Hernandez-Andrade E, Scheier M, Dezerega V, Carmo A, Nicolaides $\mathrm{KH}$. Fetal middle cerebral artery peak systolic velocity in the inves- tigation of non-immune hydrops. Ultrasound Obstet Gynecol 2004; 23: 442-5. [CrossRef]

17. Deren O, Onderoglu L. The value of middle cerebral artery systolic velocity for initial and subsequent management in fetal anemia. Eur J Obstet Gynecol Reprod Biol 2002; 101: 26-30. [CrossRef]

18. Dukler D, Oepkes D, Seaward G, Windrim R, Ryan G. Noninvasive tests to predict fetal anemia: a study comparing Doppler and ultrasound parameters. Am J Obstet Gynecol 2003; 188: 1310-4. [CrossRef]

19. Baschat AA, Harman CR, Alger LS, Weiner CP. Fetal coronary and cerebral blood flow in acute fetomaternal hemorrhage. Ultrasound Obstet Gynecol 1998; 12: 128-31. [CrossRef]

20. Yamaguchi Y, Tsukimori K, Hojo S, Nakanami N, Nozaki M, Masumoto $\mathrm{K}$, et al. Spontaneous rupture of sacrococcygeal teratoma associated with acute fetal anemia. Ultrasound Obstet Gynecol 2006; 28: 720-2. [CrossRef]

21. Capponi A, Rizzo G, Rinaldo D, Arduini D, Romanini C. The effects of fetal blood sampling and placental puncture on umbilical artery and fetal vessels blood flow velocity waveforms. Am J Perinatol 1996; 13: 185-90. [CrossRef]

22. Weinraub Z, Avrech OM, Golan A, Zabow P, Ron-El R, Bukovsky I, et al. Indomethacin and amniocentesis-induced changes in fetal flow velocity waveforms. Ultrasound Obstet Gynecol 1992; 2: 104-6. [CrossRef]

23. Calışkan E, Ozkan S, Cakıroğlu Y, Yalçınkaya O, Polat A, Corakçı A. The effects of maternal anxiety prior to amniocentesis on uterine and fetal umbilical blood flow. J Turk Ger Gynecol Assoc 2009; 10: 162-7. 